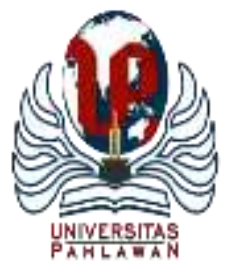

Edukatif : Jurnal Ilmu Pendidikan Volume 4 Nomor 1 Tahun 2022 Halm 1051 - 1064

EDUKATIF: JURNAL ILMU PENDIDIKAN

Research \& Learning in Education

https://edukatif.org/index.php/edukatif/index

\title{
Analisis Riset Penerapan Model Pembelajaran Inkuiri Terbimbing Berbasis Literasi Sains dalam Pembelajaran Fisika
}

\author{
Salsabila Happy Millenia ${ }^{1 凶}$, Titin Sunarti ${ }^{2}$ \\ Universitas Negeri Surabaya, Indonesia ${ }^{1,2}$ \\ E-mail : $\underline{\text { salsabilahappy3600@ gmail.com }}^{1},{\underline{\text { titinsunarti@ } \text { unesa.ac.id }^{2}}}^{2}$
}

\begin{abstract}
Abstrak
Penelitian ini memiliki tujuan menganalisis pembelajaran inkuiri terbimbing berbasis literasi sains meliputi metode, media pembelajaran, kemampuan yang diukur dan instrumen penilaian dalam pembelajaran fisika, materi fisika. Penelitian ini merupakan penelitian kepustakaan dengan analisis bibliometrik. Pengumpulan data sekunder penelitian menggunakan Publish or Perish (PoP) berupa artikel lima tahun terakhir (2016-2020) pada google scholar dan scopus. Hasil analisis 21 artikel penelitian terdahulu menyimpulkan bahwa model inkuiri terbimbing mempengaruhi kemampuan literasi sains menggunakan metode penelitian eksperimen dalam pembelajaran. Media pembelajaran paper test digunakan untuk mengoptimalkan literasi siswa. Kemampuan yang diukur memakai model inkuiri terbimbing berbasis literasi sains, diantaranya peningkatan literasi sains siswa, pemahaman konsep fisika, pemecahan masalah, motivasi belajar, serta hasil belajar siswa. Instrumen penilaian tes tulis seperti multiple choice, essay, uraian, dan deskripsi sering digunakan dengan pengembangan butir soal menyesuaikan indikator literasi sains. Materi fisika bahasan hukum Newton berkaitan fenomena ilmiah sering diujikan dalam literasi sains. Riset ini diharapkan sebagai referensi penelitian selanjutnya dalam menganalisis penerapan model inkuiri terbimbing berbasis literasi sains dalam pembelajaran fisika secara lengkap dan mendalam.
\end{abstract}

Kata Kunci: literasi sains, fisika, model inkuiri terbimbing.

\begin{abstract}
This study aims to analyze guided inquiry learning based on scientific literacy including methods, learning media, measured abilities and assessment instruments in physics learning, physics material. This research is library research with bibliometric analysis. The secondary data collection of the research used Publish or Perish (PoP) in the form of articles for the last five years (2016-2020) on Google Scholar and Scopus. The results of the analysis of 21 previous research articles concluded that the guided inquiry model affected scientific literacy skills using experimental research methods in learning. Paper test learning media is used to optimize student literacy. The abilities measured using a guided inquiry model based on scientific literacy include increasing students' scientific literacy, understanding physics concepts, problem-solving, learning motivation, and student learning outcomes. Written test assessment instruments such as multiple-choice, essay, description, and description are often used with the development of items according to scientific literacy indicators. Materials related to Newton's laws of physics are often tested in scientific literacy. This research is expected to be a reference for further research in analyzing the application of a guided inquiry model based on scientific literacy in physics learning in a complete and in-depth manner.
\end{abstract}

Keywords: scientific literacy, physics, guided inquiry model.

Copyright (c) 2022 Salsabila Happy Millenia, Titin Sunarti

$\triangle$ Corresponding author:

Email : salsabilahappy3600@gmail.com

DOI : https://doi.org/10.31004/edukatif.v4i1.2027

ISSN 2656-8063 (Media Cetak)

ISSN 2656-8071 (Media Online)

Edukatif : Jurnal Ilmu Pendidikan Vol 4 No 1 Tahun 2022 p-ISSN 2656-8063 e-ISSN 2656-8071 
1052 Analisis Riset Penerapan Model Pembelajaran Inkuiri Terbimbing Berbasis Literasi Sains dalam Pembelajaran Fisika - Salsabila Happy Millenia, Titin Sunarti

DOI: https://doi.org/10.31004/edukatif.v4i1.2027

\section{PENDAHULUAN}

Pada abad ke-21 kemendikbud merumuskan bahwa paradigma pembelajaran abad- 21 menekankan pada keahlian anak didik dalam mencari pengetahuan dalam bermacam sumber, merumuskan kasus, berfikir analitis serta bekerjasama dalam menuntaskan sesuatu kasus. Dengan kemajuan pada era ke- 21, orang dituntut untuk mengikuti perkembagan ilmu serta teknologi terutama pada dunia pembelajaran (Dewi \& Sunarti, 2018). Salah satu metode untuk tingkatkan mutu siswa dalam perihal wawasan, tindakan serta keahlian merupakan literasi sains. Memahami keahlian literasi sains orang mempunyai peluang lebih besar pada kehidupan.

Keahlian literasi ilmu terdapat tiga ialah menerangkan kejadian dengan cara ilmiah, menilai serta mengonsep penyeledikan ilmiah, serta menginterpretasi data serta fakta ilmiah (OECD, 2016). Seorang yang mempunyai literasi ilmu merupakan orang yang memakai konsep sains, memiliki keahlian proses sains untuk bisa mengevaluasi dan membuat ketetapan sehari hari apabila berkaitan dengan orang sekelilingnya, lingkungan, serta menguasai interaksi antara sains, teknologi serta warga termasuk juga perkembagan teknologi serta sosial. Suatu pembelajaran dapat tercapai apabila menerapkan kompetensi tersebut untuk melatih kemampuan literasi sains siswa.

Penelitian yang dilaksanakan oleh Programme for International Student Assesment (PISA) tahun 2012, kemampuan literasi sains peserta didik di Indonesia yang mendapatkan peringkat ke 64 dari 65 negara peserta (OECD, 2013). Tahun 2015 literasi sains peserta didik Indonesia berada mendapatkan peringkat 62 dari 70 negara peserta (OECD, 2018). Hasil survey terakhir yaitu pada tahun 2018 literasi sains peserta didik Indonesia berada pada peringkat 70 dari 78 negara peserta (OECD, 2019). Berdasarkan data tersebut menunjukkan bahwa kemampuan literasi sains siswa di Indonesia dari berbagai tahun masih rendah dibandingkan kemampuan literasi sains negara lain di dunia. Hal ini dikarenakan siswa di Indonesia belum menerapkan konsep IPA dalam kehidupanya setiap hari.

Kemampuan literasi sains mencakup pada bidang Ilmu Pengetahuan Alam (IPA), salah satunya adalah fisika, yang mempunyai peranan berarti dalam kemajuan ilmu serta teknologi. Pengembangan keahlian anak didik dalam aspek fisika ialah salah satu kunci kesuksesan peningkatan keahlian dalam membiasakan diri memasuki dunia teknologi (Indrawati, 2018). Lewat mata pelajaran fisika anak didik dapat meningkatkan keahlian berasumsi analitis induktif serta deduktif dalam menuntaskan permasalahan yang berhubungan dengan kejadian alam sekitar.

Kemampuan literasi sains mencakup pada bidang Ilmu Pengetahuan Alam (IPA), salah satunya adalah fisika, yang memiliki peranan penting dalam perkembangan sains dan teknologi. Pengembangan kemampuan siswa dalam bidang fisika merupakan salah satu kunci keberhasilan peningkatan kemampuan dalam menyesuaikan diri memasuki dunia teknologi (Indrawati, 2018). Melalui mata pelajaran fisika siswa mampu mengembangkan kemampuan berpikir analitis induktif dan deduktif dalam menyelesaikan masalah yang berkaitan dengan peristiwa alam sekitar.

Berdasarkan permasalahan diatas, terdapat beberapa upaya alternatif untuk meningkatkan kemampuan literasi sains siswa dengan model pembelajaran yang efisien dan menarik perhatian peserta didik yaitu model inkuiri terbimbing (guided inquiry). Model pembelajaran inkuiri terbimbing membagikan peluang pada anak didik untul aktif ikut serta dalam proses pembelaharan dengan melaksanakan penyelidikan serta jalan keluar permasalahan dengan cara mandiri, tetapi senantiasa dengan edukasi guru supaya anak didik lebih mudah dalam menguasai konsep pelajaran (Hanafiah, 2009). Tahap pelaksanaan model inkuiri terbimbing, meliputi: 1) orientasi, 2) merumuskan permasalahan, 3) merumuskan asumsi, 4) pengumpulan data, 5) menguji asumsi, 6) merumuskan kesimpulan. Kesuksesan model ini bergantung pada keinginan anak didik untuk beraktifitas memakai kemampuannya dalam memecahkan permasalahan (Yanti, 2019). 
1053 Analisis Riset Penerapan Model Pembelajaran Inkuiri Terbimbing Berbasis Literasi Sains dalam Pembelajaran Fisika - Salsabila Happy Millenia, Titin Sunarti

DOI: https://doi.org/10.31004/edukatif.v4i1.2027

Tujuan penelitian ini yaitu digunakan menganalisis penerapan model pembelajaran inkuiri terbimbing berbasis literasi sains dalam pembelajaran fisika ditinjau berdasarkan metode, media pembelajaran, materi fisika, kemampuan yang diukur dan jenis instrumen penilaian. Perihal ini penting digunakan sebagai penyaluran serta gambaran riset literasi sains yang sudah dilakukan. Hasilnya diharapkan bisa memberikan bimbingan dalam melaksanakan riset, perbaikan ataupun kebijaksanaan lebih lanjut (Nurhasanah et al., 2020).

\section{METODE PENELITIAN}

Penelitian ini menggunakan jenis penelitian library research (penelitian kepustakaan) bertujuan menganalisis penerapan model pembelajaran inkuiri terbimbing berbasis literasi sains dalam pembelajaran fisika dengan menggunakan metode analisis bibliometrik. Analisis bibliometrik digunakan untuk mengevaluasi kemajuan pengetahuan dalam literatur menggunakan pendekatan matematis dan statistika (Ayudha \& Setyarsih, 2021).

Data penelitian yang digunakan pada penelitin ini yaitu data sekunder yang didapatkan dari artikel jurnal dan proseding rentang waktu 5 tahun terakhir (2016-2020) dan didapatkan sebanyak 19 artikel jurnal dan 2 artikel proseding. Pengambilan data penelitian ini dilakukan pada bulan November 2021. Perolehan data dijelaskan pada diagram alur yang dapat dilihat pada Gambar 1.

\section{Pengumpulan data melalui aplikasi Publish or Perish ( $P o P$ ) melalui pencarian berdasarkan judul dan kata kunci Pengumpulan literatur dari Scopus dan Google Scholar:}

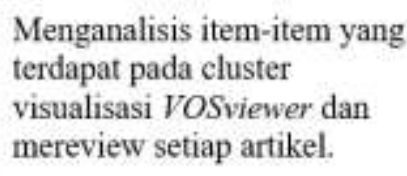

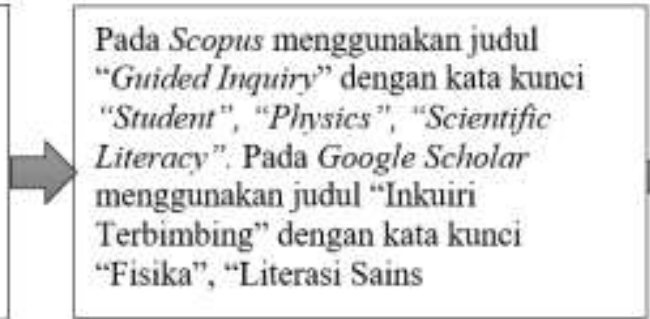

\section{Memvisualisasi artikel} menggunakan VOSviewer berdasarkan kesamaan katakata pada judul dan abstrak
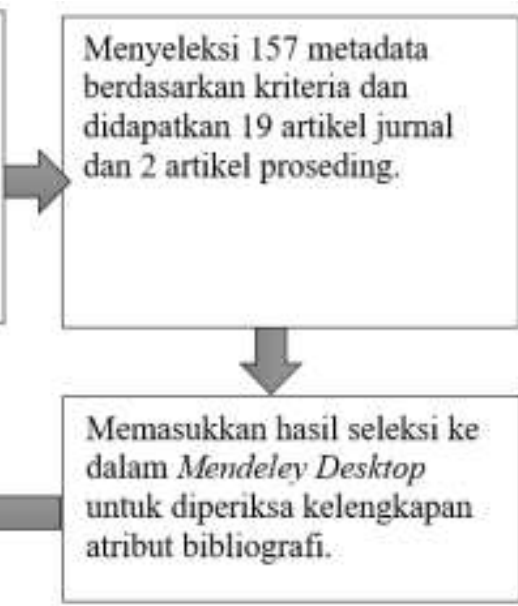

\section{Gambar 1. Diagram Alur Penelitian}

Hasil pemetaan bibliometrik menggunakan perhitungan Co-Occurrence pada VOSviewer. Analisis $\mathrm{Co}$ Occurrence dilakukan untuk mengetahui riset dalam menggunakan topik tersebut. Kata kunci yang semakin sering berhubungan atau berpasangan menunjukkan terdapat hubungan antar kata kunci.

\section{HASIL DAN PEMBAHASAN PENELITIAN}

Berdasarkan hasil penelitian diperoleh 21 artikel penerapan model pembelajaran inkuiri terbimbing berbasis literasi sains pada pembelajaran fisika. Salah satu topik penelitian dalam pembelajaran fisika yang mulai mendapatkan perhatian adalah penelitian literasi sains, karena sangat berpengaruh dalam kehidupan teknologi dan era sains ini. Gambar 2 menampilkan bahwa penelitian ini selama periode tahun 2016 hingga 2020 mengalami peningkatan dan penurunan pada tahun 2017. 
1054 Analisis Riset Penerapan Model Pembelajaran Inkuiri Terbimbing Berbasis Literasi Sains dalam Pembelajaran Fisika - Salsabila Happy Millenia, Titin Sunarti

DOI: https://doi.org/10.31004/edukatif.v4i1.2027

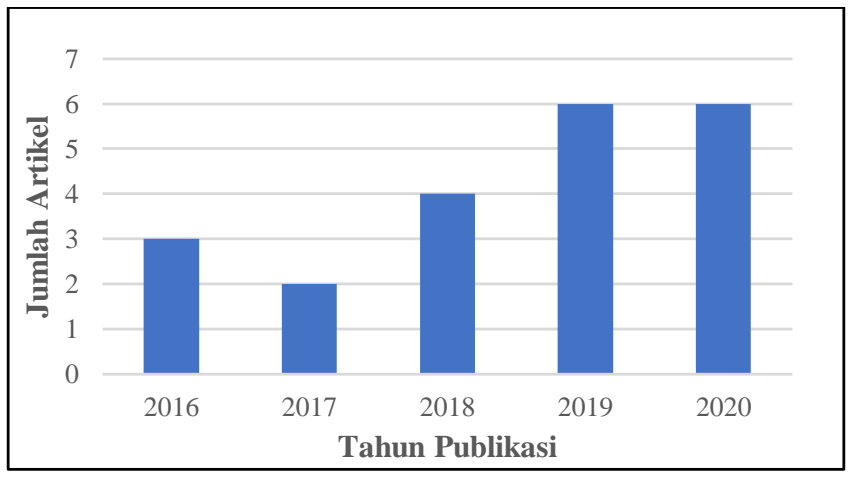

Gambar 2. Publikasi Artikel Tahun 2016-2020

Berdasarkan gambar diatas, artikel mengenai penerapan model pembelajaran inkuiri terbimbing berbasis literasi sains pada pembelajaran fisika paling banyak dipublikasikan pada tahun 2019 dan 2020 yaitu berjumlah 6 artikel. Sedangkan, paling sedikit pada tahun 2017. Penelitian tersebut masih perlu adanya penelitian lebih lanjut. Penggunaan literasi sains dapat memecahkan suatu permasalahan salah satunya fisika yang secara tidak langsung berkaitan dalam kehidupan sehari-hari.

Analisis keterkaitan antar kata-kata yang membentuk jaringan artikel satu dengan artikel lain akan menghasilkan beberapa cluster yang ditunjukkan oleh network visualization VOSviewer. Gambar 3 merupakan hasil temuan pada penelitian ini dengan kata kunci "ability", "student" dan "physics" memiliki node yang besar dibandingkan lainnya, yang menunjukkan adanya hubungan antara kemampuan siswa dalam pembelajaran fisika.

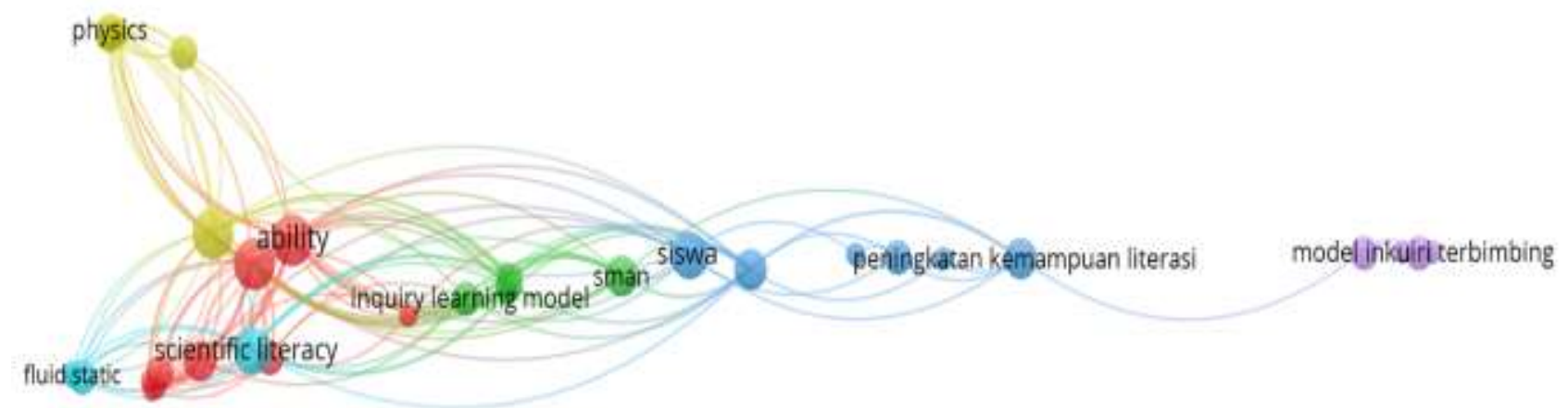

\section{Gambar 3. Network Visualization VOSviewer terhadap kata kunci}

Berdasarkan visualisasi pada VOSviewer tersebut, pemetaan kesamaan kata kunci artikel dibedakan menjadi beberapa cluster dengan warna beberapa item sesuai dengan rumusan masalah penelitian dapat dilihat pada Tabel 1.

\section{Tabel 1}

Pemetaan Cluster pada VOSviewer

\begin{tabular}{ccl}
\hline Cluster & Warna & \multicolumn{1}{c}{ Topik Bahasan pada Cluster } \\
\hline 1 & Merah & $\begin{array}{l}\text { Ability, experimental class, multiple choice question, newton, non equivalent control } \\
\text { design, pre post design control, research, scientific literacy skill, study }\end{array}$ \\
\hline 2 & Hijau & $\begin{array}{l}\text { Guided inquiry learning, high scholl student, inquiry learning model, newtons law } \\
\text { material, pre experimental design study, sman }\end{array}$ \\
\hline 3 & Biru Tua & $\begin{array}{l}\text { Berbantuan multimedia, group posttest pretest design, inquiry materi usaha dan } \\
\text { energi, kemampuan literasi, peningkatan kemampuan literasi, siswa }\end{array}$ \\
\hline 5 & Kuning & $\begin{array}{l}\text { development } 4 d, \text { physics, Problem, science literacy, student, web students } \\
\text { worksheet }\end{array}$ \\
\hline Ungu & $\begin{array}{l}\text { Mendeskripsikan pemahaman konsep, model inkuiri terbimbing, peserta didik, } \\
\text { science literacy skill }\end{array}$ \\
\hline
\end{tabular}


1055 Analisis Riset Penerapan Model Pembelajaran Inkuiri Terbimbing Berbasis Literasi Sains dalam Pembelajaran Fisika - Salsabila Happy Millenia, Titin Sunarti

DOI: https://doi.org/10.31004/edukatif.v4i1.2027

\begin{tabular}{ccc}
\hline Cluster & Warna & Topik Bahasan pada Cluster \\
\hline 6 & Biru Muda & fluid static, posttest design, scientific literacy, Senior high school \\
\hline
\end{tabular}

Keterkaitan topik-topik penelitian ditampilkan pada density visualization seperti Gambar 4 dibawah ini.

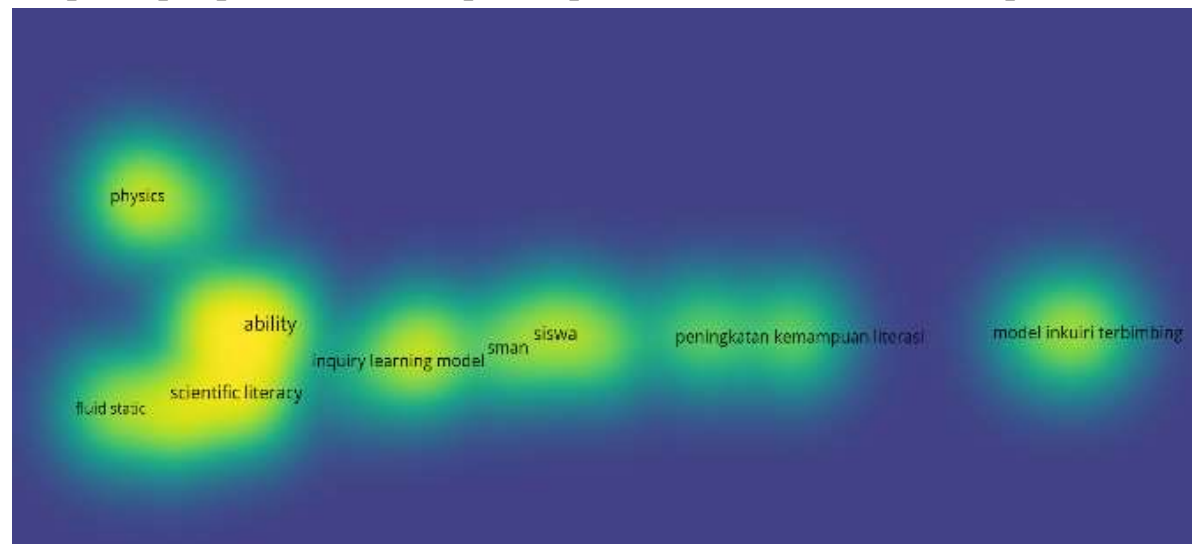

Gambar 4. Density Visualization VOSviewer

Hasil visualisasi didapatkan kata kunci "ability" dan "scientific literacy" yang memiliki warna kuning cerah dibandingkan kata kunci lainnya dapat dikatakan topik tersebut sudah banyak dilakukan dalam penelitian. Sedangkan, kata kunci dengan warna semakin pudar artinya topik masih jarang diteliti (Waltman, 2013). Kata kunci dengan warna yang hampir tidak terlihat ditunjukkan pada "berbantuan media" dan "web students worksheet", artinya topik tersebut jika dilakukan penelitian kemungkinan akan menghasilkan sebuah kebaruan (novelty) yang tinggi.

Hasil pemetaan kata kunci pada 21 artikel menghasilkan variabel-variabel penelitian terkait penerapan model pembelajaran inkuiri terbimbing berbasis literasi sains dalam pembelajaran fisika. Beberapa topik bahasan pada cluster menemukan keterkaitan antar variabel dan dilakukan identifikasi kembali berdasarkan metode penelitian, media pembelajaran, kemampuan yang diukur, instrumen penilaian dalam pembelajaran fisika, dan materi fisika yang digunakan dalam literasi sains sebagai berikut.

\section{Metode Penelitian}

Hasil analisis artikel diperoleh rincian metode penelitian yang digunakan ditunjukkan pada Tabel 2 berikut.

Tabel 2

Pengelompokkan Metode Penelitian

\begin{tabular}{ll}
\hline Metode Penelitian & \multicolumn{1}{c}{ Peneliti } \\
\hline Quasi Experimental & (Rewalino et al., 2020); (Apriliana et al., 2019); (Sari et al., 2020); (Agustina et al., \\
& 2020); (Iskandar et al., 2019); (Iskandar et al., 2019); (Parno et al., 2020). \\
\hline True Experimental & (Ardiningtyas, D \& Jatmiko, 2019); (Dewi \& Sunarti, 2018); (Latukau, 2016) \\
\hline Pre Experimental & $\begin{array}{l}\text { (Shellawati \& Sunarti, 2018); (Nurfadhilah, 2016); (Tamara \& Sunarti, 2017); } \\
\text { (Haryadi \& Pujiastuti, 2020) }\end{array}$ \\
\hline $\begin{array}{l}\text { Research and } \\
\text { Development }\end{array}$ & (Yuliana et al., 2019); (Putra, 2016); (Devitri, 2019); (Sastradika \& Jumadi, 2018); \\
\hline Eksperimen & (Batong \& Wilujeng, 2018) \\
\hline $\begin{array}{l}\text { Deskriptif } \\
\text { Kuantitatif }\end{array}$ & (Istiquahrial, 2017) \\
\hline
\end{tabular}

Penelitian eksperimen digunakan untuk mengetahui pengaruh terhadap perlakuan (treatment) tertentu. Berdasarkan Tabel 2 diatas dapat dilihat bahwa metode yang sering digunakan yaitu quasi experimental. Sesuai pada cluster warna hijau. Metode ini merupakan desain penelitian yang memiliki kelompok kontrol terhadap variabel-variabel luar. 
1056 Analisis Riset Penerapan Model Pembelajaran Inkuiri Terbimbing Berbasis Literasi Sains dalam Pembelajaran Fisika - Salsabila Happy Millenia, Titin Sunarti

DOI: https://doi.org/10.31004/edukatif.v4i1.2027

Penelitian Ardiningtyas \& Jatmiko (2019); Dewi \& Sunarti (2018); dan Latukau (2016) menggunakan metode true experimental merupakan desain penelitian yang menggunakan sampel yang diambil secara acak dari populasi itu digunakan sebagai eksperimen. Metode pre experimental merupakan desain penelitian yang tidak ada variabel kontrol serta sampel tidak dipilih secara acak dikarenakan pengaruh dari variabel luar terhadap variabel dependen.

Penggunaan metode R\&D juga sering dilakukan buat meningkatkan serta memvalidasi produk yang hendak dipakai dalam pembelajaran. Riset Istiqomah \& Hariyono (2019) dan Santoso \& Madlazim (2020) menggunakan metode deskriptif kuantitatif yaitu penelitian yang menjelaskan fenomena, mendeskripsikan gejala, dan menggambarkan peristiwa secara faktual, sistematis (Sugiyono, 2016).

\section{Media Pembelajaran}

Media pembelajaran merupakan media visualisasi yang dipakai dalam pelaksanaan pembelajaran. Salah satunya pembelajaran fisika yang membutuhkan pemahaman tentang konsep-konsep yang terkait satu sama lain. Media yang digunakan dari 21 artikel terdapat 2 penelitian yang berbasis online menggunakan teknologi berupa web-LKPD yang dilakukan oleh Batong \& Wilujeng (2018) dan Iskandar et al (2019) berupa aplikasi Edmodo. Kelebihan yang didapatkan dengan penggunaan media pembelajaran online yaitu belajar secara fleksibel artinya dapat dilakukan dimana saja dan tidak terbatasi waktu.

Berdasarkan penelitian mengenai media pengambilan data yang paling tepat yaitu berbasis paper test yang mampu meningkatkan pemahaman ilmiah dan siswa mudah mengingat materi. Literasi sains menerapkan pembelajaran yang memiliki tujuan untuk memajukan keterampilan literasi siswa dengan membaca sebuah bacaan fenomena ilmiah.

\section{Kemampuan yang Diukur}

Penerapan model inkuiri terbimbing berbasis literasi sains terdapat kemampuan yang diukur secara rinci akan dijelaskan pada Tabel 3.

Tabel 3

Kemampuan Siswa yang Diukur

\begin{tabular}{lcl}
\hline $\begin{array}{l}\text { Kemampuan } \\
\text { yang Diukur }\end{array}$ & $\begin{array}{c}\text { Jumlah } \\
\text { Artikel }\end{array}$ & \multicolumn{1}{c}{ Peneliti } \\
\hline $\begin{array}{l}\text { Meningkatkan } \\
\text { Literasi Sains }\end{array}$ & 16 & $\begin{array}{l}\text { (Agustina et al., 2020); (Batong \& Wilujeng, 2018); (Devitri, 2019); (Dewi } \\
\text { \& Sunarti, 2018); (Haryadi \& Pujiastuti, 2020); (Iskandar et al., 2019); } \\
\text { (Istiqomah \& Hariyono, 2019); (Nurfadhilah, 2016); (Parno et al., 2020); } \\
\text { (Putra, 2016); (Rewalino et al., 2020); (Santoso, 2020); (Sari et al., 2020); } \\
\text { (Sastradika \& Jumadi, 2018); (Shellawati \& Sunarti, 2018); (Tamara \& } \\
\text { Sunarti, 2017); (Yuliana et al., 2019) }\end{array}$ \\
\hline $\begin{array}{l}\text { Pemahaman } \\
\text { Konsep }\end{array}$ & 2 & (Latukau, 2016) \\
\hline $\begin{array}{l}\text { Pemecahan } \\
\text { Masalah }\end{array}$ & 1 & (Ardiningtyas \& Jatmiko, 2019) \\
\hline $\begin{array}{l}\text { Motivasi } \\
\text { Belajar }\end{array}$ & 1 & (Apriliana et al., 2019) \\
\hline Hasil Belajar & 1 & (Syahrial, 2017) \\
\hline
\end{tabular}

\section{Meningkatkan Literasi Sains}

Pembelajaran berbasis inkuiri terbimbing bisa meningkatkan keahlian literasi sains siswa karena tahapan belajar siswa sesuai dengan perkembangan kognitif Piaget menyatakan bahwa siswa mampu berpikir abstrak dan memecahkan masalah melalui percobaan. Literasi sains digunakan mengukur kemampuan pengetahuan sains siswa dalam mengidentifikasi masalah dan menyimpulkan masalah berdasarkan isu-isu sains. Kemampuan literasi sains siswa didapatkan dari pre-test yang dilakukan sebelum pembelajaran dilakukan dan post-test dicoba sebelum pembelajaran buat mengetahui kenaikan yang didapatkan oleh anak 
1057 Analisis Riset Penerapan Model Pembelajaran Inkuiri Terbimbing Berbasis Literasi Sains dalam Pembelajaran Fisika - Salsabila Happy Millenia, Titin Sunarti

DOI: https://doi.org/10.31004/edukatif.v4i1.2027

didik sehabis memperoleh penataran bentuk inkuiri terbimbing. Langkah-langkah model inkuiri dapat dilatihkan kompetensi literasi sains sehingga kemampuan literasi sains siswa meningkat sebagaimana terlihat pada Tabel 4.

Tabel 4

Hasil Analisis Pengaruh Model Inkuiri Terbimbing Terhadap Peningkatan Literasi Sains Siswa pada Tahun 2016-2020

\begin{tabular}{|c|c|c|}
\hline Tahun & Peneliti & Hasil Penelitian \\
\hline 2016 & $\begin{array}{l}\text { (Nurfadhilah, } \\
\text { 2016); (Putra, } \\
\text { 2016) }\end{array}$ & $\begin{array}{l}\text { Inkuiri terbimbing melatihkan literasi sains siswa dalam memahami, } \\
\text { meimplementasikan pengetahuan, menemukan sesuatu dan memecahkan } \\
\text { masalah melalui praktikum dan pencarian informasi. Hasil analisis ketercapaian } \\
\text { indikator soal dan kemampuan literasi sains setiap level meningkat. Level } \\
\text { literasi tertinggi adalah level } 4 \text { dengan } n \text {-gain sebesar 0,625 dimana } \\
\text { mengomunikasikan keputusan sesuai pengetahuan ilmiah dan bukti. }\end{array}$ \\
\hline 2017 & Sun & $\begin{array}{l}\text { Pembelajaran inkuiri terbimbing memfasilitasi siswa mencoba menemukan } \\
\text { konsep masing-masing dan menghubungkan dengan fenomena dalam } \\
\text { kehidupan sehari-hari dengan hasil berupa meningkatnya kemampuan literasi } \\
\text { sains siswa. Peningkatan tersebut terlihat dari n-gain sebesar 0,7-0,8 } \\
\text { berkategori tinggi. }\end{array}$ \\
\hline 20 & $\begin{array}{l}\text { (Batong \& } \\
\text { Wilujeng, } \\
\text { 2018); (Dewi } \\
\text { \& Sunarti, } \\
\text { 2018); } \\
\text { (Sastradika \& } \\
\text { Jumadi, 2018); } \\
\text { (Shellawati \& } \\
\text { Sunarti, 2018) }\end{array}$ & $\begin{array}{l}\text { Tingkat literasi sains menggunakan model pembelajaran inkuiri terbimbing } \\
\text { tergolong lebih banyak dibanding dengan pembelajaran konvensional. Sehingga } \\
\text { mengindikasikan bahwa siswa mengeksplorasi permasalahan dengan } \\
\text { bimbingan guru sehingga siswa mampu menggunakan pikirannya sendiri untuk } \\
\text { menemukan jawaban. Hasil penelitian Batong \& Wilujeng (2018), } \\
\text { menggunakan sumber belajar yang efektif berupa web-LKPD untuk menarik } \\
\text { minat belajar dan menambah pemahaman materi. Sedangkan untuk penelitian } \\
\text { Sastradika \& Jumadi (2018) pengembangan model inkuiri terbimbing mata } \\
\text { pelajaran pedagogi memberikan kesempatan siswa aktif secara ilmiah. Pada } \\
\text { penelitian Dewi \& Sunarti (2018) menghubungkan jawaban siswa antara sains, } \\
\text { teknologi dan lingkungan. Penelitian Shellawati \& Sunarti (2018), kompetensi } \\
\text { literasi sains menginterpretasi data serta bukti ilmiah memiliki peningkatan } \\
\text { paling tinggi. }\end{array}$ \\
\hline
\end{tabular}

2019 (Devitri,

2019); Bentuk pembelajaran fisika akan lebih mudah apabila dibantu dengan media

(Iskandar et pembelajaran yang bisa meningkatkan kemampuan literasi sains murid. Pada al., 2019); (Istiqomah \& Hariyono, 2019); penelitian Devitri (2019) menggunakan modul fisika bernuansa inkuiri terbimbing berorientasi proses sebagai sumber belajar kreatif. Selain itu, multimedia berbasis konstruktivitis yang dilakukan oleh Yuliana et al., (2019) juga mampu menarik minat belajar siswa secara mandiri dan sistematis. Media (Yuliana et al., 2019) pembelajaran secara online seperti aplikasi Edmodo digunakan pada penelitian Iskandar et al., (2019) karena siswa dapat belajar secara fleksibel dan meningkatkan kemampuan teknologi dalam literasi sains. Penelitian Istiqomah \& Hariyono (2019) menunjukkan peningkatan kompetensi literasi sains antara lain kompetensi 1: menerangkan fenomena ilmiah dan kompetensi 3: menilai (evaluasi) serta merancang penyelidikan.

2020 (Agustina et al., 2020); (Haryadi \& Pujiastuti, 2020); (Parno et al., 2020); (Rewalino et al., 2020); (Santoso, Penerapan inkuiri terbimbing menekankan proses pembelajaran yang mampu memberi peningkatan literasi sains dikarenakan fase-fase model pembelajaran dan pendekatan yang digunakan. Pada penelitian Parno et al., (2020) dan Santoso (2020) menggunakan pendekatan STEM yang melibatkan keaktifan siswa dalam memecahkan permasalahan ilmiah terkait konsep yang diajukan secara kontekstual. Kemampuan literasi sains dengan model inkuiri terbimbing lebih baik dibandingkan model pembelajaran lain. Penelitian Agustina et al., (2020) membuktikan model inkuiri memberikan pengaruh positif terhadap literasi sains dibandingkan model direct instruction. Sedangkan, penelitian 
1058 Analisis Riset Penerapan Model Pembelajaran Inkuiri Terbimbing Berbasis Literasi Sains dalam Pembelajaran Fisika - Salsabila Happy Millenia, Titin Sunarti

DOI: https://doi.org/10.31004/edukatif.v4i1.2027

\begin{tabular}{lll}
\hline Tahun & \multicolumn{1}{c}{ Peneliti } & \multicolumn{1}{c}{ Hasil Penelitian } \\
\hline 2020); (Sari et & Rewalino et al., (2020) membandingkan dengan model pembelajaran discovery \\
al., 2020) & yang membiarkan siswa berkembang sesuai kemampuan masing-masing. \\
& $\begin{array}{l}\text { Peningkatan literasi sains terhadap tiga indikator dibuktikan pada penelitian } \\
\text { Haryadi \& Pujiastuti (2020) dengan nilai n-gain sebesar 0,4046 berkategori } \\
\end{array}$ & sedang.
\end{tabular}

Pada penelitian relevan terjadi peningkatan literasi sains murid setelah diterapkannya model pembelajaran inkuiri terbimbing. Kondisi tersebut disebabkan langkah-langkah model inkuiri dapat dilatihkan pada kompetensi literasi sains antara lain: 1) menjelaskan fenomena ilmiah, hal ini dilatihkan pada fase 1 dan fase 2 model pembelajaran inkuiri dimana siswa dituntut mengidentifikasi masalah peristiwa dan menentukan hipotesis; 2) mengevaluasi dan merancang penemuan ilmiah, aspek ini pada fase 3 dan fase 4 model pembelajaran inkuiri dimana siswa mencari informasi sesuai data dan fakta melalui eksperimen; 3) menginterpretasi data dan bukti ilmiah, aspek ini pada fase 5 dan fase 6 model pembelajaran inkuiri dimana siswa mempresentasikan hasil data yang didapatkan dan menyimpulkan.

Berdasarkan analisis riset menunjukkan persentase ketercapaian hasil kemampuan literasi sains tiap indikator pada aspek pengetahuan dan kompetensi sebagai berikut.

Tabel 5

Hasil Kemampuan Literasi Sains Per Indikator Aspek Kompetensi Sains

\begin{tabular}{lc}
\multicolumn{1}{c}{$\begin{array}{c}\text { Indikator Aspek } \\
\text { Kompetensi Sains }\end{array}$} & Persentase \\
\hline Mengidentifikasi isu ilmiah & $65,80 \%$ \\
\hline Menjelaskan fenomena ilmiah & $63,36 \%$ \\
\hline $\begin{array}{l}\text { Menginterpretasikan data dan } \\
\text { bukti ilmiah }\end{array}$ & $70,96 \%$ \\
\hline
\end{tabular}

(Sumber: Wulandari \& Sholihin, 2016)

\begin{tabular}{lc}
\multicolumn{1}{c}{\begin{tabular}{c}
\multicolumn{1}{c}{ Indikator Aspek } \\
Kompetensi Sains
\end{tabular}} & Persentase \\
\hline Mengidentifikasi masalah ilmiah & $56,43 \%$ \\
\hline Menjelaskan fenomena ilmiah & $54,43 \%$ \\
\hline $\begin{array}{l}\text { Menggunakan data dan bukti } \\
\text { ilmiah }\end{array}$ & $59,67 \%$ \\
\hline
\end{tabular}

Berdasarkan Tabel 5, persentase diperoleh untuk mencari rata-rata kemampuan literasi siswa yang dicapai masing-masing indikator. Hasil kemampuan literasi sains terdapat aspek kompetensi sains yang dicapai siswa secara signifikan pada penelitian Wulandari \& Sholihin (2016) dan Sujudi et al (2020) ialah indikator menginterpretasi data dan bukti ilmiah sebesar 70,96\% dan 59,67\%. Selanjutnya, disusul oleh indikator mengidentifikasi masalah ilmiah sebesar $65,80 \%$ dan $56,43 \%$. Sedangkan, indikator paling rendah adalah menjelaskan fenomena ilmiah sebesar $63,36 \%$ dan 54,43\%. Kemampuan menginterpretasi data dan bukti ilmiah dibuktikan siswa dalam mengidentifikasi masalah dan menyimpulkan sesuai konsep ilmiah (OECD, 2013). Kemampuan mengevaluasi dan merancang penemuah ilmiah ditunjukkan dengan mengevaluasi fenomena kemudian menghubungkan dengan aspek pengetahuan sains yang dimiliki siswa. Sedangkan, kemampuan menjelaskan fenomena ilmiah menunjukkan kemampuan siswa dalam memecahkan soal literasi sains sesuai konsep ilmiah yang dipahami pada materi. Aspek kompetensi sains melibatkan proses mental dalam menyelesaikan dan memecahkan masalah.

Pencapaian kemampuan literasi sains dibuktikan dengan mengidentifikasi data berdasarkan gambar fenomena ilmiah dan tabel pada instrumen tes literasi sains yang digunakan penelitian. Butir soal literasi berkaitan erat dengan aspek kognitif fenomena ilmiah dalam kehidupan sehari-hari. Siswa yang dituntut untuk menemukan dan memecahkan permasalahan melalui praktikum dan pencarian informasi, kemudian menghubungkan fenomena dalam kehidupan sehari-hari. Pernyataan tersebut sesuai dengan hasil penelitian yang menunjukkan kemampuan berpikir tingkat tinggi dan perilaku sikap ilmiah.

\section{Pemahaman Konsep}

Menurut penelitian Latukau (2016), model inkuiri terbimbing digunakan untuk menganalisis pemahaman konsep melalui literasi sains dan membandingkan dengan model pembelajaran konvensional yang 
1059 Analisis Riset Penerapan Model Pembelajaran Inkuiri Terbimbing Berbasis Literasi Sains dalam Pembelajaran Fisika - Salsabila Happy Millenia, Titin Sunarti

DOI: https://doi.org/10.31004/edukatif.v4i1.2027

digunakan di sekolah dengan memberikan soal pilihan ganda (multiple choice) sebagai tes akhir pemahaman konsep fisika. Hasil penelitian terdapat perbedaan hasil skor pemahaman konsep fisika melalui literasi sains pada kelas yang menerapkan model inkuiri terbimbing dan kelas konvensional. Skor rata-rata pemahaman konsep yang menggunakan model inkuiri terbimbing lebih baik dibandingkan pembelajaran konvensional.

Model pembelajaran inkuiri efektif dalam meningkatkan hubungan konseptual. Faktor yang terpenting dalam pemahaman konsep ialah memecahkan suatu permasalahan terkait isu-isu sains pada kehidupan seharihari dalam pembelajaran fisika.

\section{Pemecahan Masalah}

Berdasarkan penelitian Ardiningtyas \& Jatmiko (2019), pre-test dan post-test sebagai penilaian kompetensi literasi sains berbasis paper test. Siswa mengerjakan soal sama sebanyak 13 soal. Hasil penelitian menunjukkan bahwa nilai rata-rata $n$-gain kedua kelas berkategori sedang dan terjadi peningkatan literasi sains pada siswa dalam pemecahan masalah yang merangsang berpikir secara kontekstual dan tingkat tinggi. Taraf signifikasi sebesar 0,05. Analisis pembelajaran pemecahan masalah lebih efektif dalam meningkatkan literasi sains siswa. Pernyataan ini dibuktikan bahwa pemecahan masalah menggunakan permasalahan yang otentik dan mengkaitkan dengan evaluasi pengalaman siswa dalam proses belajar untuk membangun pemahaman (Tan, 2003).

Penyebab kesulitan siswa dalam memecahakan masalah yaitu lingkungan literasi yang kurang dan pengajar menggunakan model pembelajaran yang tidak sesuai untuk melatihkan siswa terkait literasi sains. Siswa kesulitan dalam menghubungkan, mengkaitkan antara konsep dan prinsip yang sesuai, menyelesaikan permasalahan dan menyimpulkan secara logis (Ningsari et al., 2021).

\section{Motivasi Belajar}

Penelitian Apriliana et al. (2019) menggunakan pembelajaran inkuiri terbimbing dengan bantuan mind mapping berupa mencatat secara kreatif dan memasukkan infromasi ke otak dalam bentuk visual. Penerapan mind mapping juga erat kaitannya dengan pengalaman kehidupan nyata, sehingga meningkatkan keterampilan proses sains. Selain mengukur keterampilan proses sains, penggunaan media mind mapping model inkuiri terbimbing juga mengukur motivasi belajar siswa terhadap sains serta kreativitas siswa (Pratiwi \& Meilani, 2018). Motivasi belajar siswa mempengaruhi kemampuan literasi sains.

Hasil penelitian menunjukkan bahwa nilai rata-rata literasi sains siswa dengan motivasi belajar tinggi sebesar 70,43 dan motivasi belajar rendah sebesar 68,50. Penyebab perbedaan motivasi belajar tersebut yaitu proses belajar mengajar, lingkungan belajar siswa, lingkungan keluarga, dan lingkungan sosial (Cahyani \& Setyawati, 2016). Analisis berdasarkan indikator motivasi belajar yang diukur ditunjukkan pada tabel berikut.

\section{Tabel 6}

Indikator Motivasi Belajar

\begin{tabular}{clc}
\hline No & \multicolumn{1}{c}{ Indikator Motivasi Belajar } & Persentase \\
\hline 1 & Antusias dalam kegiatan pembelajaran & $78,13 \%$ \\
\hline 2 & Rajin menyelesaikan tugas & $83,56 \%$ \\
\hline 3 & Mampu menghadapi kesulitan & $83,25 \%$ \\
\hline 4 & Menerapkan cara-cara kognitif belajar & $73,45 \%$ \\
\hline 5 & Melakukan pekerjaan secara mandiri & $73,97 \%$ \\
\hline 6 & Suka mencari dan menyelesaikan permasalahan & $81,70 \%$ \\
\hline 7 & Sukar melepas sesuatu yang dipercayai & $80,67 \%$ \\
\hline 8 & Kecenderungan berusaha supaya berhasil & $86,34 \%$ \\
\hline 9 & Belajar dengan inisiatif sendiri & $81,70 \%$ \\
\hline (Sumber: Melinda et al., 2021)
\end{tabular}

Pada Tabel 6, menunjukkan bahwa tingginya motivasi belajar siswa dalam indikator kecenderungan berusaha supaya berhasil sebesar $86,34 \%$. Sedangkan rendahnya motivasi belajar siswa ditunjukkan pada indikator menerapkan cara-cara kognitif belajar sebesar 73,45\%. Kesulitan siswa menggunakan cara-cara 
1060 Analisis Riset Penerapan Model Pembelajaran Inkuiri Terbimbing Berbasis Literasi Sains dalam Pembelajaran Fisika - Salsabila Happy Millenia, Titin Sunarti

DOI: https://doi.org/10.31004/edukatif.v4i1.2027

kognitif dalam belajar disebabkan terdapat siswa yang tidak mempelajari materi terlebih dahulu sebelum pelajaran dan tidak me-review kembali pelajaran setelah diberikan (Melinda et al., 2021).

\section{Hasil Belajar}

Berdasarkan penelitian Syahrial et al. (2017), menerapkan model inkuiri terbimbing membiarkan siswa belajar untuk menemukan masalah berdasarkan fakta, konsep dan prinsip yang merupakan aspek literasi sains. Penilaian formatif berupa 12 soal essay sebagai tes kognitif untuk mengetahui hasil belajar siswa. Penelitian ini menghasilkan nilai rata-rata hasil belajar siswa menggunakan model inkuiri terbimbing lebih tinggi dibandingkan dengan menerapkan pembelajaran konvensional.

Penyebab perbedaan hasil belajar yaitu adanya pengaruh dari model pembelajaran yang digunakan dalam kelas. Teori belajar konstruktivitisme menyatakan bahwa pengetahuan terbentuk oleh konstruksi kognitif terhadap objek, pengalaman, dan lingkungan. Sejalan dengan penelitian oleh Khotimah \& Partono (2015), pembelajaran inkuiri terbimbing secara signifikan mempengaruhi hasil belajar siswa dalam fisika, karena pembelajaran fisika mencakup pengetahuan yang menuntut siswa dalam keterampilan proses.

\section{Instrumen Penelitian}

Penelitian ialah melakukan pengukuran menggunakan alat ukur yang baik. Alat ukur tersebut disebut instrumen penilaian. Instrumen merupakan alat ukur penilaian untuk mengukur capaian kognitif siswa setelah dilakukan pembelajaran (Purwanto, 2006). Menurut PISA 2006 terdapat 4 aspek yang dilakukan penilaian ialah 1) kompetensi (proses); 2) pengetahuan; 3) konteks (aplikasi); 4) sikap (OECD, 2007). Hasil analisis pada 21 artikel menunjukkan bahwa jenis instrumen yang dilakukan peneliti dengan memberikan tes kepada siswa, serta terdapat beberapa bentuk penilaian pada Tabel 7.

Tabel 7

Jenis Instrumen dan Bentuk Penilaian

\begin{tabular}{cll}
\hline $\begin{array}{c}\text { Jenis } \\
\text { Instrumen }\end{array}$ & $\begin{array}{c}\text { Bentuk } \\
\text { Penilaian }\end{array}$ & \multicolumn{1}{c}{ Peneliti } \\
\hline Tes tertulis & $\begin{array}{l}\text { Objektif } \\
\text { (multiple } \\
\text { choice) }\end{array}$ & (Sastradika \& Jumadi, 2018); (Latukau, 2016) \\
\cline { 2 - 4 } & $\begin{array}{l}\text { Subjektif } \\
\text { (essay) }\end{array}$ & $\begin{array}{l}\text { (Ardiningtyas Budi, 2019); (Iskandar et al., 2019); (Istiqomah \& } \\
\text { Hariyono, 2019); (Parno et al., 2020); (Rewalino et al., 2020); (Sari et al., }\end{array}$ \\
\cline { 2 - 4 } & $\begin{array}{l}\text { 2020); (Shellawati \& Sunarti, 2018); (Tamara \& Sunarti, 2017) } \\
\text { (uraian) }\end{array}$ & (Apriliana et al., 2019); (Syahrial, 2017) \\
\cline { 2 - 4 } & Deskripsi & (Batong \& Wilujeng, 2018); (Haryadi \& Pujiastuti, 2020) \\
\cline { 2 - 4 } & (Agustina et al., 2020); (Devitri, 2019); (Dewi \& Sunarti, 2018); \\
& (Nurfadhilah, 2016); (Putra, 2016); (Santoso, 2020); (Yuliana et al., \\
\hline
\end{tabular}

Berdasarkan pengelompokkan di atas, penelitian mengungkapkan pengambilan data berupa tes tertulis pre-test yang dilakukan sebelum pembelajaran, kemudian setelah pembelajaran diberikan post-test untuk mengetahui peningkatan kemampuan literasi sains siswa. Terdapat beberapa penelitian yang tidak berfokus pada bentuk penilaian yang digunakan.

Berdasarkan analisis literatur data penelitian, bentuk tes subjektif berupa soal essay paling sering diganakan pada tes literasi sains. Tes essay merupakan penilaian dalam berbagai indikator level kognitif, mengetahui, memahami, menerapkan, menganalisis, mengevaluasi dan mengembangkan. Siswa dapat mendeskripsikan jawaban sesuai kemampuan pengetahuan yang dimiliki. Pernyataan tersebut sejalan dengan kompetensi literasi sains, yaitu menjelaskan fenomena ilmiah; mengevaluasi dan merancang rumusan masalah ilmiah; dan menginterpretasikan data dan bukti ilmiah (OECD, 2013). Parno et al., (2020) menyatakan bahwa 
1061 Analisis Riset Penerapan Model Pembelajaran Inkuiri Terbimbing Berbasis Literasi Sains dalam Pembelajaran Fisika - Salsabila Happy Millenia, Titin Sunarti

DOI: https://doi.org/10.31004/edukatif.v4i1.2027

pengembangan butir soal harus berdasarkan topik materi yang disesuaikan dengan indikator literasi sains. Bentuk penilaian tes subjektif ternyata memiliki kelemahan seperti penulisan yang kurang jelas, sistematika tidak tersusun secara hierarkis meskipun jawaban benar, poin pokok sedikit.

Penelitian Latukau, (2016) dan Sastradika \& Jumadi, (2018) menggunakan bentuk penilaian yang memberikan kemudahan siswa dalam menyelesaikan tes berpikir tingkat tinggi. Tes objektif seperti soal pilihan ganda (multiple choice) merupakan soal yang sudah diberikan beberapa pilihan jawaban, kemudian memilih hanya satu jawaban yang benar. Tes pilihan ganda memiliki kelebihan yaitu memberikan kemudahan saat dikoreksi (Pendidikan, 2019). Selain tes objektif, juga terdapat tes non-objektif atau tes uraian, merupakan pertanyaan yang menuntut siswa untuk menguraikan dan menyatakan permasalahan soal sesuai kemampuan pengetahuan masing-masing (Pendidikan, 2019). Syahrial et al., (2017) menyusun butir soal tes uraian materi yang diajarkan sesuai dengan indikator, sehingga dapat meningkatkan kemampuan siswa.

\section{Materi yang Digunakan dalam Literasi Sains}

Penerapan literasi sains bertujuan untuk mengetahui suatu permasalahan berkaitan kehidupan seharihari, salah satunya dalam pembelajaran fisika. Pembelajaran fisika dapat meningkatkan kemampuan siswa dalam berpikir untuk menyelesaikan masalah sekitar. Berdasarkan hasil analisis literatur, penggunaan materi dalam literasi sains dengan menerapkan model inkuiri terbimbing yang diberikan pada siswa ditunjukkan pada Gambar 4.

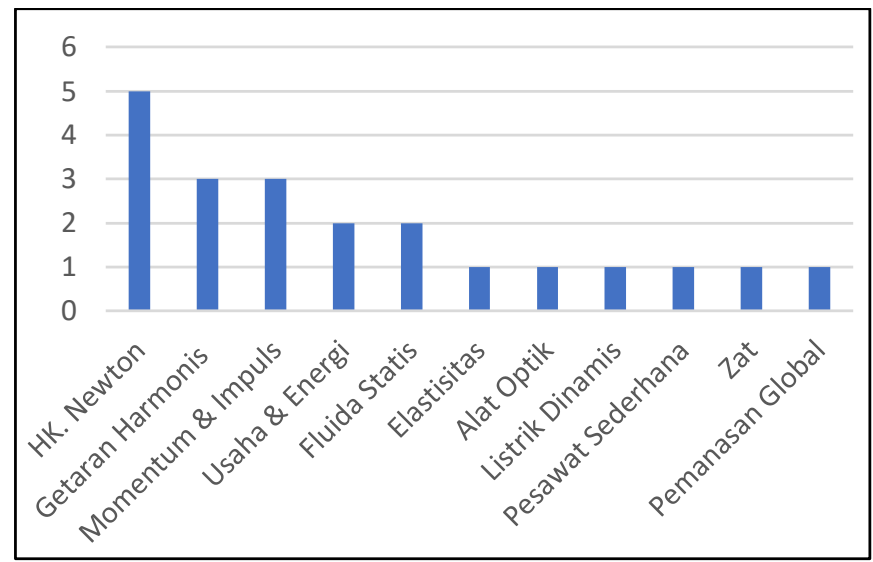

\section{Gambar 5. Materi Fisika yang Digunakan dalam Literasi Sains}

Materi fisika yang lebih sering digunakan dalam literasi sains adalah materi tentang hukum Newton yang ditemukan pada 5 artikel. Keefektifan penggunaan model pembelajaran inkuiri terbimbing berbasis literasi sains dapat membantu siswa dalam mengidentifikasi fenomena-fenomena terkait isu-isu sains didalamnya, termasuk pada materi hukum Newton yang mendorong siswa untuk melakukan eksperimen secara langsung dengan mengamati, menyelidiki dan menganalisis di sekitarnya.

\section{KESIMPULAN}

Berdasarkan pemetaan dan analisis yang telah dipaparkan di atas, topik penelitian penerapan model pembelajaran inkuiri terbimbing berbasis literasi sains dalam pembelajaran fisika, dapat disimpulkan bahwa pada tahun 2016-2020 yang dipublikasikan pada jurnal google scholar maupun scopus mengalami penurunan dan kenaikan, yang berarti perlu adanya penelitian lebih lanjut. Penerapan model inkuiri terbimbing memiliki pengaruh terhadap kemampuan literasi sains. Metode penelitian eksperimen menjadi dominasi dalam mengoptimalkan pembelajaran. Sesuai dengan pernyataan Piaget bahwa siswa mampu mengidentifikasi dan memecahkan masalah melalui percobaan. Penggunaan media dalam literasi sains meningkatkan siswa dalam pemahaman materi, termasuk paper test sering digunakan dalam pengambilan data dan diaplikasikan dalam online (web dan aplikasi) untuk meningkatkan pemahaman materi. Pembelajaran inkuiri terbimbing dalam 
1062 Analisis Riset Penerapan Model Pembelajaran Inkuiri Terbimbing Berbasis Literasi Sains dalam Pembelajaran Fisika - Salsabila Happy Millenia, Titin Sunarti

DOI: https://doi.org/10.31004/edukatif.v4i1.2027

literasi sains dapat digunakan untuk mengukur peningkatan literasi sains, pemahaman konsep fisika, pemecahan masalah, motivasi belajar, dan hasil belajar siswa. Bentuk penilaian literasi sains yang dapat digunakan yaitu multiple choice, essay, uraian, deskripsi. Pengembangan butir soal disesuaikan indikator literasi sains. Materi hukum Newton sebagai pokok bahasan yang sering diujikan dalam literasi sains. Penelitian ini diharapkan dapat menjadi referensi bagi para peneliti selanjutnya dalam menganalisis penerapan model inkuiri terbimbing berbasis literasi sains pada pembelajaran fisika secara lengkap dan mendalam.

\section{DAFTAR PUSTAKA}

Agustina, I. R., Andinasari, A., \& Lia, L. (2020). Kemampuan Literasi Sains Pada Materi Zat Melalui Model Pembelajaran Inkuiri Terbimbing Berbantuan Multimedia. Jurnal Pendidikan Fisika. http://fkip.ummetro.ac.id/journal/index.php/fisika/article/view/2491

Apriliana, S., Sundaygara, C., \& Ayu, H. D. (2019). Pengaruh Model Pembelajaran Guide Inquiry Berbantuan Mind Mapping terhadap Literasi Sains Ditinjau dari Motivasi Belajar Siswa. In Prosiding Seminar http://snpfmotogpe.ulm.ac.id/proceeding/index.php/snpf/article/view/62

Ardiningtyas, D., \& Jatmiko, B. (2019). Peningkatan Literasi Sains Siswa Sma Melalui Penerapan Model Pembelajaran Inkuiri Terbimbing Dan Model Pembelajaran Berdasarkan Masalah. IPF: Inovasi Pendidikan Fisika, 846-850.

Ayudha, C. F. H., \& Setyarsih, W. (2021). Studi Literatur: Analisis Praktik Pembelajaran Fisika Di Sma Untuk Melatih Keterampilan Pemecahan Masalah. Jurnal Pendidikan Fisika Undiksha, 11(1), 16. https://doi.org/10.23887/jjpf.v11i1.33427

Batong, J. S. T., \& Wilujeng, I. (2018). Developing Web-Students' Worksheet Based on Inquiry Training for Increase Science Literacy. Journal of Physics: Conference Series, 1097(1). https://doi.org/10.1088/1742-6596/1097/1/012021

Devitri, N. (2019). Validity Of Physics Module Nuanced Model Of Process Oriented Guided Inquiry Learning (POGIL) To Improve Scientific Literacy At 10th Grade Senior High School. In Journal of Physics: Conference Series (Vol. 1185, Issue 1). https://doi.org/10.1088/1742-6596/1185/1/012060

Dewi, N. A. R., \& Sunarti, T. (2018). Upaya Meningkatkan Kemampuan Literasi Sains Dengan Model Pembelajaran Guided Inquiry Pada Sma Untuk Materi Alat Optik. Inovasi Pend. 07(03), 381-384.

Hanafiah, N., \& Sahana, C. (2009). Konsep Strategi Pembelajaran. Bandung: PT. Refika Aditama.

Haryadi, R., \& Pujiastuti, H. (2020). The Science Literacy Capabilities Profile Using Guided Inquiry Learning Models. Jurnal Penelitian \& Pengembangan Pendidikan Fisika, 6(1), 81-88. https://doi.org/10.21009/1.06109

Indrawati, M. D. (2018). Pengembangan Instrumen Penilaian Literasi Sains Fisika Peserta Didik pada Bahasan Gelombang Bunyi di SMA Negeri 1 Gedangan Sidoarjo. Jurnal Inovasi Pendidikan Fisika (JIPF), 07(01), 14-20.

Iskandar, Sastradika, D., \& Defrianti, D. (2019). Optimizing Inquiry-based Learning Activity in Improving Students' Scientific Literacy Skills. Journal of Physics: Conference Series, 1233(1). https://doi.org/10.1088/1742-6596/1233/1/012061

Istiqomah, C. Z., \& Hariyono, E. (2019). Peningkatan Literasi Sains Siswa Dengan Menggunakan Model Pembelajaran Guided Inquiry. In Inovasi Pendidikan Fisika ISSN: (Vol. 8, Issue 5, pp. 682-685).

Khotimah, L. N. R., \& Partono. (2015). Pengaruh Model Pembelajaran Inkuiri Terbimbing Terhadap Hasil Belajar Fisika Siswa Kelas VIII SMP Negeri 4 Metro Semester Genap Tahun Pelajaran 2013/2014. Jurnal Pendidikan Fisika (JPF), 3(1)

Latukau, R. H. (2016). Pengaruh Pendekatan Literasi Sains Dengan Model Inkuiri Terbimbing Terhadap Pemahaman Konsep Fisika Siswa SMA Negeri 1 Leihitu Maluku Tengah. eprints.unm.ac.id. http://eprints.unm.ac.id/3197/ 
1063 Analisis Riset Penerapan Model Pembelajaran Inkuiri Terbimbing Berbasis Literasi Sains dalam Pembelajaran Fisika - Salsabila Happy Millenia, Titin Sunarti

DOI: https://doi.org/10.31004/edukatif.v4i1.2027

Melinda, S., Purwanto, A., \& Putri, H. (2021). Analisis Motivasi Belajar Siswa Tingkat SMA dalam Pembelajaran Fisika. Jurnal Ilmiah Pendidikan Fisika, 5(3).

Ningsari, I. S., Zainuddin, A., \& Setyarsih, W. (2021). Kajian Literatur Instrumen Isomorfik Sebagai Asesmen Pembelajaran Fisika. ORBITA: Jurnal Kajian, Inovasi Dan Aplikasi Pendidikan Fisika, 7(1), 54. https://doi.org/10.31764/orbita.v7i1.4407

Nurfadhilah, F. (2016). Penerapan Model Pembelajaran Inkuiri Untuk Melatihkan Literasi Sains Siswa Pada Materi Listrik Dinamis Di SMA Negeri 1 Sumberrejo. Inovasi Pendidikan Fisika, 98-104. https://jurnal.unesa.ac.id/index.php/inovasi-pendidikan-fisika/article/view/19950

Nurhasanah, N., Jumadi, J., Herliandry, L. D., Zahra, M., \& Suban, M. E. (2020). Perkembangan Penelitian Literasi Sains Dalam Pembelajaran Fisika di Indonesia. Edusains, 12(1), 38-46. https://doi.org/10.15408/es.v12i1.14148

Organization for Economic Cooperation Development (OECD) PISA 2016. (2007). Science Competencies for Tomorrow's World Volume 1: Analysis. Paris: OECD Publishing.

Organization for Economic Cooperation Development (OECD) PISA 2012. (2013). Assessment Framework Key Competencies in Reading, Science, Problem Solving and Financial Literacy. Paris: OECD Publishing.

Organization for Economic Cooperation Development (OECD) PISA 2015. (2016). Assessment Framework Key Competencies in Reading, Mathematics and Science. Paris: OECD Publishing.

Organization for Economic Cooperation Development (OECD) PISA 2015. (2018). PISA Result in Focus. Paris: OECD Publishing.

Organization for Economic Cooperation Development (OECD) PISA 2018. (2019). PISA 2018 Result Combined Executive Summaries. Paris: OECD Publishing.

Parno, Yuliati, L., Munfaridah, N., Ali, M., Indrasari, N., \& Rosyidah, F. U. N. (2020). The Impact Of STEMBased Guided Inquiry Learning On Students' Scientific Literacy In The Topic Of Fluid Statics. Journal of Physics: Conference Series, 1481(1). https://doi.org/10.1088/1742-6596/1481/1/012104

Pendidikan, P. P. (2019). Panduan Penilaian Tertulis.

Pratiwi, I. T. M., \& Meilani, R. I. (2018). Peran Media Pembelajaran Dalam Meningkatkan Prestasi Belajar Siswa. Jurnal Pendidikan Manajemen Perkantoran, 3(2), 33. https://doi.org/10.17509/jpm.v3i2.11762

Purwanto, N. (2006). Psikologi Pendidikan. Bandung: PT Remaja Rosdakarya.

Putra, M. I. S. (2016). Implementasi Pembelajaran IPA Model Inkuiri Terbimbing Untuk Meningkatkan Keterampilan Literasi Sains Calon Guru MI. Dirasat: Jurnal Manajemen Dan Pendidikan .... https://test.journal.unipdu.ac.id/index.php/dirasat/article/view/540

Rewalino, Y. I., Supriyatman, S., \& Kade, A. (2020). Pengaruh Model Pembelajaran Inkuiri Terbimbing Terhadap Kemampuan Literasi Sains Siswa. Jurnal Pendidikan Fisika http://jurnal.untad.ac.id/jurnal/index.php/EPFT/article/view/17193

Santoso, G. M. (2020). Validitas Perangkat Pembelajaran Model Inkuiri Terbimbing Menggunakan Pendekatan Stem Untuk Meningkatkan Kemampuan Literasi Sains Siswa. 09(02), 144-148.

Sari, P. A. Y., Andriani, N., \& Rizaldi, W. R. (2020). Implementasi Pembelajaran IPA Berbasis Inkuiri Terbimbing Terhadap Kemampuan Literasi Sains Materi Pesawat Sederhana. Literasi Pendidikan Fisika. http://jurnal.fkip.unmul.ac.id/index.php/JLPF/article/view/352

Sastradika, D., \& Jumadi. (2018). Development Of Subject-Specific Pedagogy Based On Guided Inquiry About Newton's Law To Improve Senior High School Students' Scientific Literacy Ability. Journal of Physics: Conference Series, 1097(1). https://doi.org/10.1088/1742-6596/1097/1/012017

Shellawati, S., \& Sunarti, T. (2018). Penerapan Model Pembelajaran Inkuiri Terbimbing Untuk Meningkatkan Kemampuan Literasi Sains Peserta Didik SMA. Inovasi Pendidikan Fisika, 7(3), 407-412. 
1064 Analisis Riset Penerapan Model Pembelajaran Inkuiri Terbimbing Berbasis Literasi Sains dalam Pembelajaran Fisika - Salsabila Happy Millenia, Titin Sunarti

DOI: https://doi.org/10.31004/edukatif.v4i1.2027

Sugiyono. (2016). Metode Penelitian Kuantitatif, Kualitatif, dan R\&D. Bandung: Penerbit Alfabeta.

Sujudi, M. S., Idris, T., Suryanti., \& Handayani, P. H. (2020). Profil Kemampuan Literasi Sains Siswa SMP Islam As-Shofa Kota Pekanbaru Berdasarkan PISA. Journal of Natural Science and Integration. 3(1), 58-69

Syahrial, F. (2017). Implementasi Model Inkuiri Terbimbing Dalam Pembelajaran Getaran Harmonis di SMA (Studi Pada Keterampilan Proses Sains, Literasi Sains dan Hasil Belajar). FKIP E-PROCEEDING. https://jurnal.unej.ac.id/index.php/fkip-epro/article/view/6356

Tamara, A. F., \& Sunarti, T. (2017). Penerapan Model Pembelajaran Guided Inquiry untuk Meningkatkan Kemampuan Literasi Sains Siswa pada Materi Elastisitas di SMAN 1 Plemahan Kediri. Jurnal Inovasi Pendidikan Fisika (, 06(03), 1-5.

Tan, O. S. (2003). Problem Based Learning Innovation: Using Problems to Power Learning in The 21st Century. Singapore: Thomson Learning

Wahyudi, L. E., \& Supardi, Z. A. I. (2013). Penerapan Model Pembelajaran Inkuiri Terbimbing Pada Pokok Bahasan Kalor Untuk Melatihkan Keterampilan Proses Sains. Jipf, 02(02), 62-65.

Waltman, L., \& van Eck, N.J. (2013). A Smart Local Moving Algorithm for Large Scale Modularity-Based Community Detection. Eur. Phys. J. B 86, 471 https://doi.org/10.1140/epjb/e2013-40829-0

Wulandari, N., \& Sholihin, H. (2016). Analisis Kemampuan Literasi Sains Pada Aspek Pengetahuan dan Kompetensi Sains Siswa SMP Pada Materi Kalor. Edusains, 8(1) 66-73 : http://journal.uinjkt.ac.id/index.php/edusains

Yanti, P. N. (2019). Pengaruh Model Pembelajaran Inkuiri Terbimbing Terhadap Literasi Sains Siswa di MTSN 2 Aceh Barat. Banda Aceh: Universitas Islam Negeri Ar-Raniry.

Yuliana, D., Hufri, Gusnedi, Syafriyani, \& Anshari, R. (2019). Validasi Multimedia Fisiska Berbasis Konstruktivis dalam Pembelajaran Inkuiri pada Hukum Newton Gravitasi dan Getaran Harmonik Sederhana untuk Meningkatkan Literasi Sains Siswa Kelas X SMA. Journal of Physics Education, 12(4), 833-840. 